\title{
PERKEMBANGAN ANGKLUNG GUBRAG: DARI TRADISI RITUAL HINGGA HIBURAN (1983-2013)
}

\author{
Oleh: \\ Alin Novandini dan Ayi Budi Santosa ${ }^{1}$
}

\begin{abstract}
This article entitled "The Development of Angklung Gubrag from Ritual Tradition to Entertainment. The main problem of this article is how the development of Angklung Gubrag art in Kecamatan Cigudeg, Kabupaten Bogor since 1983-2013. This research has target to describe the backround of the beginning of Angklung Gubrag arts, the development of Angklung Gubrag arts, the efforts of artist do to converst this art, and the efforts of government to push and keep the art of Angklung Gubrag. The method which used in this research is historical method which consist of heuristic, critics, interpretation, and historiography. Angklung Gubrag is one of the art which comes from Kecamatan Cigudeg Kabupaten Bogor. Arts of Angklung Gubrag growth on society that has system of animism and dinamism. Firstly, it is shown as ritual media on the ceremony of Seren Taun which held to respect Nyi Pohaci. As tradisional arts, it was handed down from one generation to the other, and it has changing a lot. It is caused by changing of thinking society and their believed. After 1983, the artist who come from Padepokan Seni Angklung Gubrag change the tradition of Seren Taun. The purpose of this changed was to make society receive this art again. So that, the Angklung Gubrag art is also changing to be an entertainment. These development gives the changes in instrument, dance, and song to estetic of the Angklung Gubrag show. Beside the artist, the goverment is also act as supporter and protector of Angklung Gubrag art.
\end{abstract}

Keywords: Angklung Gubrag Arts, Seren Taun Ceremony, Padepokan Seni Angklung Gubrag

\section{PENDAHULUAN}

Kebudayaan yang tercipta dalam yang mengalami perkembangan dari masyarakat tidak terlepas dari adanya interaksi atau aktifitas sesama anggota masyarakatnya. Keanekaragaman kehidupan yang dimiliki setiap suku bangsa menjadikan kebudayaan daerah dapat diangkat sebagai jati diri daerah masingmasing. Salah satu unsur kebudayaan masa ke masa adalah kesenian. Kesenian yang ada di tiap daerah akan berbeda satu dengan yang lainnya. Beberapa hal yang mempengaruhi ciri khas kesenian masingmasing daerah tentunya berkaitan dengan lingkungan geografis, pola interaksi masyarakat, hubungan dengan masyarakat

${ }^{1}$ Alin Novandini adalah mahasiswa pada Departemen Pendidikan Sejarah FPIPS UPI, Ayi Budi Santosa adalah dosen pembimbing I. Penulis dapat dihubungi di nomor 085720064055 / alamat email : alinnovandini@gmail.com 
lain, dan juga kepercayaan yang diyakini masyarakat tersebut.

Salah satu kesenian tradisional yang dikenal oleh sebagian besar masyarakat Indonesia adalah Angklung. Angklung merupakan salah alat musik yang berasal dari etnis Sunda. Angklung tersebar di seluruh wilayah Jawa Barat dengan nama dan cara penyajian yang berbeda. Beberapa kesenian Angklung yang tersebar pada masyarakat Sunda menurut Soepandi (1974, hlm. 12), di antaranya Angklung Baduy (Kanekes), Angklung Gubrag (Bogor), Angklung Buncis, Angklung Dogdog Lojor, dan Angklung Badeng. Kelima kesenian Angklung ini memiliki keunikan dan ciri khasnya sendiri.

Pada mulanya, angklung-angklung tersebut tidak digunakan sebagai seni pertunjukkan, melainkan hanya dimainkan pada upacara-upacara ritual. Salah satu Angklung yang masih bertahan sampai saat ini adalah Angklung Gubrag yang berasal dari Kecamatan Cigudeg, Kabupaten Bogor. Angklung yang digunakan dalam media ritual merupakan angklung buhun atau angklung tua pada masyarakat Sunda. Angklung yang termasuk tua mempunyai ciri-ciri yaitu mempunyai ukuran yang besar sekitar setengah sampai satu meter, instrumen yang digunakan hanya enam buah angklung dan dogdog, tidak menampilkan tarian, serta bahan bambu yang digunakan harus melalui proses pemilihan yang sesuai dengan tradisi. Berdasarkan ciri tersebut, Angklung Gubrag termasuk ke dalam salah satu angklung buhun.

Perkembangan Angklung Gubrag sebagai seni tradisional mengalami tantangan perubahan zaman. Masyarakat yang sudah berpikir modern mulai meninggalkan semua kegiatan yang bersangkutan dengan mistis dan adat istiadat karena dianggap kuno. Dalam bidang kesenian, terjadi permasalahan yang menyangkut selera masyarakat. Sebagian besar masyarakat mulai beralih pada seni modern karena keseniankesenian tradisional yang ada masih dirasakan terdapat kekurangan (O.A Yoety, 1985 hlm. 10).

Salah satu contoh nyata mengenai perubahan zaman tersebut adalah ketika tempat-tempat penyimpanan padi (leuit) yang dahulu dianggap penting dan sakral mulai ditinggalkan. Masyarakat yang mengenal teknologi mengganti leuit dengan tempat penyimpanan yang lebih praktis. Perubahan pemikiran tersebut, berpengaruh kepada kesenian Angklung sendiri. Semenjak leuit kehilangan fungsinya di tengah masyarakat, maka hal tersebut menyebabkan upacara ritual untuk menghormati padi mulai ditinggalkan karena dianggap tidak terlalu penting dan berpengaruh terhadap hasil panen.

Berdasarkan permasalahan di atas, penulis tertarik untuk mengkaji mengenai perkembangan Angklung Gubrag. Alasan pertama yakni kesenian tradisional Angklung pada umumnya tumbuh pada masyarakatkampung adat. Berbeda dengan kesenian Angklung lainnya, Angklung Gubragtumbuhpadamasyarakatyangtidak menganut sistem adat. Berdasarkan hal tersebut, perkembangan Angklung Gubrag di tengah masyarakat akan berbeda dan menarik untuk dikaji. Kesenian Angklung Gubrag telah mengalami pasang surut, berbagai generasi telah berupaya terus menerus untuk menghidupkan kesenian Angklung Gubrag agar tetap bertahan. Kesenian Angklung Gubrag yang sekarang 
masih ada dan berkembang belum begitu dikenal oleh masyarakat setempat pada umumnya. Selain itu penulis tertarik untuk mengkaji peran seniman, dan pemerintah dalam mempertahankan kesenian asal daerahnya.

Masalah utama yang diangkat dalam penelitian ini yakni bagaimana perkembangan kesenian Angklung Gubrag di Kecamatan Cigudeg Kabupaten Bogor pada tahun 1983-2013. Periode tahun 1983 diangkat sebagai titik awal kesenian Angklung Gubrag dimana kesenian ini mulai mengalami perubahan ke arah seni pertunjukan yang bersifat menghibur. Pementasan kesenian Angklung Gubrag ini tentunya tidak lagi dalam rangka tradisi ritual, melainkan juga sebagai hiburan yang mencerminkan keluhuran budaya masyarakat lokal. Kemudian, penelitian ini dibatasi sampai tahun 2013 saat beridirinya gedung Padepokan Seni Angklung Gubrag yang diresmikan dan disahkan oleh pemerintah.

Dalam mengkaji penelitian ini, penulis memilih beberapa konsep yang digunakan sebagai acuan dalam menjawab pertanyaan penelitian. Konsep yang digunakan yakni kebudayaan yang digunakan untuk menganalisis posisi kesenian Angklung Gubrag dalam kebudayaan masyarakatnya. Seni tradisional, seni pertunjukan dan alat musik tradisional Angklung. Kemudian landasan teori yang digunakan yakni teori perubahan sosial budaya. Pemilihan landasan teori perubahan sosial budaya sangat relevan karena kesenian Angklung Gubrag,karenamerupakan salah satu unsur budaya yang mengalami perubahan. Selain itu, teori ini sesuai dengan permasalahan pada perkembangan Angklung Gubrag dengan menganalisis berdasakan faktor- faktor yang menyebabkan perubahan sosial budaya yang terjadi pada masyarakat pendukung kesenian ini3 3 Soekanto "Sosiologi suatu pengantar" 2007, hlm 283.

\section{METODE PENELITIAN}

Penelitian ini dikaji dengan menggunakan metode historis. Metode historis sendiri memiliki pengertian yakni suatu proses pengkajian, penjelasan, dan penganalisaan secara kritis terhadap rekaman serta peninggalan masa lampau (Gottschalk 2008, hlm 39). Metode historis merupakan metode yang sesuai untuk digunakan dalam penelitian ini karena data-data yang digunakan menyangkut dengan peristiwa masa lampau. Metode historis terdiri dari empat tahap antara lain heuristik, kririk sumber, interpretasi, dan historiografi. Hasil yang diharapkan dari penelitian ini adalah hasil yang objektif untuk memberikan pemahaman yang utuh berdasarkan pemikiran penulis. Untuk itu, penulis berusaha melakukan penelitian sebaikmungkin dengan mengikutilangkahlangkah penelitian yang telah dipilih.

Langkah pertama yang dilakukan dalam penelitian ini yakni heuristik atau pengumpulan sumber. Pada tahap ini, penulis menggunakan tiga teknik pengumpulan data yakni studi literatur, wawancara, dan studi dokumentasi. Dalam penelitian ini, penulis mengumpulkan dua jenis sumber yakni sumber tertulis (literatur) dan sumber lisan (wawancara).

Hal tersebut dilakukan karena pembahasan mengenai kesenian Angklung Gubrag merupakan kajian sejarah lokal. Oleh sebab itu, sumber berupa data lisan berperan sangat penting guna membandingkan data yang berupa sumber 
tertulis. Sumber tertulis dapat ditemukan pada beberapa tempat antara lain perpustakaan UPI Bandung, perpustakaan Batu Api, perpustakaan ISBI Bandung, dan sumber dari internet. Sedangkan sumber lisan didapatkan dari hasil wawancara anggota Padepokan Seni Angklung Gubrag, tokoh masyarakat, pegawai pemerintah, dan masyarakat.

Langkah kedua dalam metode historis adalah kiriksumber atau verifikasiterhadap sumber yang terdiri dari dua tahap kritik eksternal dan internal (Sjamsuddin, 2007 hlm 27). Secara sederhana kritik eksternal merupakan tahapan verifikasi terhadap aspek luar sumber. Pada tahap ini penulis melakukan kajian terhadap sumber lisan dengan ketentuan umur yang sesuai dengan tahun kajian, sehat jasmani dan pikiran, serta memiliki keterkaitan dengan kesenian Angklung Gubrag. Sedangkan kritik internal, penulis melakukan verifikasi terhadap sumber tertulis dengan memilih buku yang memiliki pembahasan dengan kajian. Kemudian sumber lisan dikaji dengan membandingkan isi wawancara antara satu narasumber dengan narasumber lain.

Tahap selanjutnya dalam metode penulisan sejarah adalah interpretasi. Interpretasi merupakan penafsiran terhadap suatu pemahaman sejarah yang berasal dari sumber-sumber dilakukan sejarawan. Hasil dari interpretasi ini berfungsi sebagai kerangka berpikir utama dari penelitian ini. Tahap interpretasi juga akan menjadi orisinalitas pemikiran dari penulis yang akan membedakannya dengan penulis lain, meskipun memiliki tema penulisan yang sama.

Tahap terakhir dalam penelitian ini adalah historiografi. Pada tahapan ini penulis menyajikan hasil temuannya pada tiga tahap sebelumnya dengan cara menyusun dalam bentuk tulisan dengan jelas dengan gaya bahasa yang sederhana menggunakan tata bahasa penulisan yang baik dan benar. Dalam historiografi penulis memaparkan semua hasil penelitiannya berdasarkan data-data dan sumber yang telah dikumpulkan dan di verifikasi sebelumnya, sehingga dapat menjawab pertanyaan penelitian.

\section{HASIL PENELITIAN DAN PEMBAHASAN}

Angklung Gubrag merupakan salah satu jenis angklung di Jawa Barat. Kesenian Angklung Gubrag tumbuh dan berkembang di Kecamatan Cigudeg Kabupaten Bogor. Kesenian tersebut sudah diwariskan oleh para leluhur secara turun temurun sebagai bagian dari hasil adat istiadat masyarakat yang sebagian besar merupakan etnis Sunda. Mayoritas masyarakat Sunda memiliki pekerjaan yang berhubungan dengan ladang. Hal tersebut erat kaitannya dengan kondisi alam di daerah sekitar Jawa Barat dan Banten yang dikelilingi oleh pegunungan sehingga masyarakat lebih banyak bekerja di ladang untuk memanfaatkan tanah yang subur di sekitarnya. Pola hidup masyarakat yang berdampingan dengan alam, menjadikan masyarakat memiliki kebudayaan yang mencerminkan kehidupannya sendiri. Keadaan masyarakat Sunda sebagai peladang dijelaskan oleh Masunah yang menjelaskan bahwa:

"Mata Pencaharian utama penduduk pada awalnya adalah berladang atau ngahuma. Ciri yang menonjol pada masyarakat peladang ini adalah kebiasaan berpindah-pindah tempat untuk mencari 
lahan yang subur. Dalam masyarakat agraris ini tumbuh subur sistem kepercayaan yang terutama berkaitan dengan sistem bercocok tanam. Mereka percaya akan adanya Sang Penguasa Alam tersebut diperlakukan sebagai pemimpin, dihormati, dan disanjung" (Masunah, 2003 hlm. 3).

Sistem mata pencaharian masyarakat Sunda yang sebagian besar bekerja di ladang, menjadikan keberlangsungan hidup mereka bergantung dari hasil panen terutama padi sebagai makanan pokok. Dalam sistem tersebut muncullah keyakinan masyarakat bahwa alam telah menyediakan segala keperluan mereka, sehingga masyarakat Sunda memiliki kepercayaan terhadap Sang Penguasa Alam yang dikenal dengan Nyi Pohaci atau Dewi Sri (Sumardjo, 2011 hlm. 94-95).

Menurut Kurnia dan Nalan (2003, hlm 23) Angklung Gubrag sudah berusia tua dan ditampilkan untuk menghormati Dewi Padi dalam kegiatan melak pare (menanam padi), ngunjal pare (mengangkut padi), dan ngadiukkeun (menempatkan) ke leuit (lumbung). Keberadaan Angklung Gubrag di tengah masyarakat Cipining merupakan salah satu ciri dari masyarakat yang percaya akan kekuatan gaib. Dalam upaya menunjukkan kepercayaan mereka, maka tercipta lah kesenian Angklung Gubrag sebagai media dalam ritual. Latar belakang munculnya Angklung Gubrag sendiri bermula ketika suatu masa masyarakat kampung Cipining mengalami kegagalan panen akibat tanaman padi diserang penyakit yang membuat butir-butir padi kosong tanpa isi. Kegagalan panen ini membuat masa paceklik berkepanjangan di wilayah Cigudeg yang menyebabkan masyarakat mengalami kelaparan. Masyarakat beranggapan kejadian tersebut sebagai kemarahan Nyi Pohaci karena tidak memperlakukan alam dengan baik.

Kejadian tersebut merupakan titik awal Angklung digunakan sebagai media ritual dalam upacara Seren Taun yang bertujuan agar Nyi Pohaci dapat memberikan kesuburan, sehingga masyarakat mendapatkan hasil panen yang melimpah. Peristiwa turunnya Nyi Pohaci dari langit inilah, akhirnya Angklung di daerah Cigudeg dikenal dengan Angklung Gubrag. Pemilihan alat musik angklung dalam ritual ini dipercaya sebagai penghubung dengan Nyi Pohaci. Alasan pemilihan Angklung sebagai media dalam upacara seren taun ini karena kepercayaan masyarakat bahwa bambu merupakan tanaman yang tumbuh dari tubuh Nyi Pohaci.

Kegiatan upacararitual yang melibatkan Angklung Gubrag kemudian dikenal masyarakat sebagai seni pertunjukan yang menjadiidentitaskelompokmereka.Upacara ritual Seren Taun biasanya dilakukan oleh masyarakat setiap akhir tahun setelah melakukan rangkaian tanam padi sebagai berikut.

1. Mengolah tanah sampai siap ditanami

2. Mengolah benih sampai siap ditanam (ngaseuk)

3. Menanam benih

4. Memelihara tanaman padi

5. Menuai padi (panen)

6. Menjemur padi

7. Mengangkut padi ke lumbung atau leuit (ngunjal)

8. Menyimpan padi (Masunah, $2003 \mathrm{hlm} .9$ ) Langkah-langkah yang dilakukan dalam rangkaian Seren Taun di antaranya mengadakanpertemuanuntukmenentukan tanggal pelaksanaan upacara Seren Taun bersama sesepuh di masyarakat Cigudeg, 
ziarah ke makam sesepuh yang sudah meninggal, melakukan doa bersama sambil melakukan sesaji, kemudian melaksanakan ritual Seren Taun dengan mengadakan pementasan Angklung Gubrag oleh pemain yang telah ditentukan. Upacara tersebut dilakukan oleh 10 orang pemain laki-laki yang terdiri atas pemain angklung Gancling, angklung Engklok, angklung Kurulung, angklung Corolot, dan dogdog.

Pelaksanaan upacara Seren Taun dilakukan dengan membunyikan Angklung Gubrag mulai dari rumah. Angklung Gubrag dibunyikan kemudian pemainnya mulai berkeliling menuju ladang atau sawah. Setelah sampai di sawah, Angklung Gubrag tetap dibunyikan kemudian juru kawih mulai memimpin doa dan membacakan kidung berisi pujipujian yang bertujuan memuja Nyi Pohaci. Masyarakat Cigudeg memiliki beberapa kidung yang merupakan ciri khas mereka, salah satunya yakni Kidung Sri Lima.

Kemudian, pada sistem laras Angklung Gubrag hanya memiliki tiga nada yang berguna untuk menyelaraskan ritme. Sumardjo (2011, hlm. 94) menjelaskan bahwa nada angklung yang tertua terdiri atas tiga nada yang merujuk pada makna tritangtu7. Konsep tritangtu dalam filosofi orang Sunda adalah semua yang ada di dunia ini memiliki lawan. Seperti dunia langit dan dunia bawah, sehingga untuk menengahi keduanya maka diciptakanlah dunia tengah yakni tempat yang dihuni oleh manusia.

Filosofi inilah yang diadopsi dalam penciptaan angklung, sehingga pada awalnya angklung hanya memiliki tiga nada. Pelaksanaan kegiatan ritual dengan menggunakan Angklung Gubrag tetap dilaksanakan oleh masyarakat Cigudeg sebagai bentuk syukur mereka terhadap Nyi Pohaci, serta bentuk penghargaan mereka terhadap warisan budaya yang telah diturunkan dari leluhur.

Perkembangan Angklung Gubrag sebagai bentuk pertunjukan media ritual tetap dipertahankan oleh masyarakat pendukungnya. Namun, beriringan dengan perubahan zaman tidak sedikit yang mulai meninggalkan upacara ritual yang menggunakan Angklung Gubrag. Kebudayaan biasanya bersifat dinamis denganmenyesuaikankeadaanmasyarakat. Maka jika salah satu unsur kebudayaan tidak lagi sesuai dengan keinginan masyarakat, kebudayaan tersebut akan hilang. Kesenian Angklung Gubrag juga mengalami berbagai tantangan dalam perkembangannya, terutama terhadap selera masyarakat.

Perubahan zaman menyebabkan kepercayaan masyarakat terhadap Nyi Pohaci semakin memudar, sehingga hal tersebut menimbulkan perubahanperubahan pada bentuk pertunjukan Angklung Gubrag. Perubahan-perubahan yang terjadi dikarenakan oleh beberapa faktor diantaranya perubahan sikap atau cara berpikir suatu masyarakat dari mistis ke rasional dan logis. Akibatnya masyarakat mulai memperhitungkan dari segi biaya, waktu, tenaga, dan urgensinya. Kedua, adanya proses modernisasi dalam pembangunan, yakni terdapat inovasi, teknologi, dan urbanisasi. Ketiga, adanya hubungan atau kontak dengan kebudayaan lain. Sikap terbuka cenderung menghasilkan warga masyarakat mudah menerima pengaruh dari kebudayaan lain.

Pada tahun 1983, terdapat pertentangan dari masyarakat mengenai pelaksanaan upacara Seren Taun yang 
dianggap menyimpang dari ajaran Islam. Berdasarkan permasalahan terjadi, dapat diketahui bahwa faktor perubahan yang terjadi pada Angklung Gubrag adalah akibat adanya kepercayaan baru yang dianut oleh masyarakat. Sehingga perubahan kepercayaan ini menimbulkan dualisme di tengah masyarakat Cigudeg. Pada satu sisi, terdapat golongan yang ingin mempertahankan kesenian Angklung Gubrag sesuai dengan ketentuan dan fungsi awalnya. Sedangkan sisi lainnya ingin menghilangkan kepercayaan terhadap Nyi Pohaci yang bersifat magis karena tidak sesuai dengan kepercayaan yang dianut. Karena perdebatan tersebut, seni Angklung Gubrag sebagai media ritual sempat tidak digunakan lagi oleh masyarakat Cigudeg.

Melihat kondisi kesenian Angklung Gubrag yang memprihatinkan, seniman dan pemain Angklung Gubrag mempunyai inisiatif untuk mendirikan sebuah padepokan seni yang mengurus mengenai kesenian Angklung Gubrag. Berdasarkan kesepakatan bersama, dilakukan beberapa perubahan dalam rangkaian upacara seren taun agar dapat diterima oleh masyarakat secara keseluruhan.

Perubahanyang pertamaadalah dengan merubah rangkaian kegiatan Seren Taun menjadi lebih dekat dengan agama Islam. Perubahan yang terjadi yakni merubah pembacaan kidung dengan memasukkan doa-doa dalam agama Islam, seperti ketika membacakan Kidung Sri Lima ketika memulai maupun mengakhiri diikuti oleh doadariagamaIslam. Selain perkembangan yang terjadi pada kidung, perubahan juga terjadi dalam pelaksanaannya. Masyarakat dan sesepuh masih menggunakan sesajen sebagai simbol penghormatan atas limpahan rejeki hasil panen yang melimpah. Namun dalam pembacaan doa, masyarakat sudah menggunakan bacaan doa dari agama Islam dan ditujukan kepada Allah. Pemilihan tanggal dilaksanakannya Seren Taun juga ditetapkan atas dasar penanggalan Islam yakni dirubah jadi bulan Muharram. Setelah tahun 2000-an, tujuan dilaksanakannya upacara Seren Taun di wilayah Cigudeg tidak berorientasi pada pemujaan Nyi Pohaci lagi, namun untuk memperingati tahun baru Hijriyyah.

Arah perkembangan Angklung Gubrag mulai terlihat sejak kesenian ini berubah bentuk menjadi seni pertunjukan yang bersifat menghibur sekitar tahun 1983 . Perkembangan bentuk pertunjukan ke arah hiburan ini adalah upaya untuk mempertahankan keberadaan Angklung Gubrag. Perubahan ini bermula saat adanya kesempatan yang diberikan oleh beberapa partai politik dianggap sebagai celah untuk memperkenalkan seni pertunjukan Angklung Gubrag pada masyarakat secara umum. Pada perkembangannya, kesenian Angklung Gubrag sebagai hiburan dipentaskan pada acara-acara sosial masyarakat seperti acara pernikahan, khitanan, penyambutan tamu, ulang tahun kabupaten Bogor, maupun acara kesenian lainnya.

Dalam bentuk pertunjukan Angklung Gubragsebagaihiburanterdapatperbedaan dengan pertunjukan yang ditujukan untuk keperluan ritual. Perbedaan pertama dapat dilihat dari penambahan peralatan dan gerakan yang dipakai dalam pertunjukan yang bersifat menghibur. Waktu yang terus berjalan menyebabkan adanya perubahan-perubahan dalam peralatan maupun struktur pertunjukan Angklung Gubrag. Perubahan yang terjadi, salah satunya adalah adanya penambahan peralatan dalam pertunjukan. Peralatan yang ditambahkan yakni kendang dan 
kecrekan.

Penambahan alat yang dipakai dalam pertunjukan hiburan disebabkani oleh beberapa hal. Pertama, adanya pengaruh dari kesenian khas Kabupaten Bogor lainnya yakni Pencak Silat. Kabupaten Bogor dikenal sebagai tempat asal Pencak Silat, khususnya untuk gerakan Cimande, Tepak Dua, dan Tepak Tilu. Dalam pertunjukankesenian PencakSilatbiasanya diiringi dengan rampak kendang. Pada perkembangannya, seniman Angklung Gubrag mengadaptasi kesenian rampak kendangtersebutsebagaipelengkapiringan Angklung Gubrag dengan tujuan agar pertunjukan lebih hidup dan berirama.

Selain terjadi penambahan peralatan, perubahan juga terjadi pada gerakan dalam pertunjukan hiburan. Penambahan dalam gerakan yakni adanya adegan bertarung menggunakan teknik silat antara dua orang pemain yang disebut dengan elaela. Kedua, adanya gerakan tarian yang dimainkan oleh ibu-ibu yang sedang memikul bakul berisi padi. Penambahan gerakan pada pertunjukan Angklung Gubrag dimaksudkan untuk menambah nilai estetika sehingga semakin menarik perhatian dari penonton.

Ketiga, perubahan pada bentuk Angklung Gubrag yang digunakan, khususnya ukuran yang dipakai. Pada perkembangannya, Angklung Gubrag juga dapat dimainkan oleh remaja dan juga anak kecil. Ukuran Angklung yang besar, sekitar satu meter menyebabkan kendala karena tidak sesuai dengan ukuran tubuh mereka yang kecil. Oleh sebab itu, dibuatlah Angklung yang berukuran lebih kecil dan sesuai untuk ukuran tubuh yang kecil. Namun untuk pemain dewasa, ukuran dan bentuknya masih sama dan tidak mengalami perubahan. Hal ini bertujuan untuk menjaga warisan yang telah diturunkan oleh para sesepuh sejak dahulu, supaya keaslian dari Angklung Gubrag tetap dipertahankan.

Keempat, penambahan lagu atau kawih. Guna menyesuaikan dengan kepentingan suatu acara, para seniman atau pemain menambahkan lagu yang bisa digunakan dengan iringan permainan Angklung Gubrag. Biasanya Angklung Gubrag digunakan pula dalam acara-acara yang bersifat sosial seperti acara maulid, pernikahan, khitanan, ataupun perayaan lainnya. Penambahan lagu yang sering digunakan yakni salawatan yang berisi puji-pujian terhadap Allah SWT.

Perkembangan bentuk pertunjukan Angklung Gubrag dari media dalam upacara ritual ke pertunjukan hiburan menunjukan adanya perubahan yang terjadi dalam sosial dan budaya masyarakat. Perubahan yang terjadi pada masyarakat disebabkan oleh pertambahan dan berkurangnya penduduk yang mempengaruhi jumlah masyarakat pendukung kesenian Angklung Gubrag. Perubahan pemikiran masyarakat ke arah modern, sehingga tradisi yang di anggap tidaksesuaidengankepribadianmasyarakat tidakdigunakanlagi.Penemuan-penemuan baru yang menyebabkan segala hal yang dianggap tradisi adalah kuno dan tidak sesuai dengan zamannya. Pertentangan yang terjadi di dalam masyarakat seperti adanya kepercayaan yang menimbulkan perbedaan pandangan masyarakat. Serta pengaruh dari kebudayaan lain, sehingga akhirnya mengikis kebudayaan awal termasuk kesenian Angklung Gubrag.

Berdasarkan faktor-faktor perubahan tersebut, menyebabkan kesenian Angklung Gubrag kurang diminati oleh masyarakat. 
Hal tersebut menyebabkan kesenian Angklung Gubrag mulai mengalami perkembangan ke arah bentuk pertunjukan hiburan. Dalammempertahankankesenian Angklung Gubrag, kelompok masyarakat yang berperan adalah para seniman dan pemain Angklung Gubrag. Usaha-usaha yang telah dilakukan oleh seniman tidak lain adalah agar dapat mengenalkan kesenian ini sebagai identitas masyarakat Cigudeg serta mewariskan seni Angklung Gubrag pada generasi selanjutnya. Adapun upaya-upaya yang dilakukan seniman untuk melestarikan kesenian Angklung Gubrag adalah sebagai berikut.

Pertama, mendirikan Padepokan Seni Angklung Gubrag. Seniman Angklung Gubrag telah banyak menghadapi tantangan dan persoalan yang berkaitan dengan keberlangsungan Angklung Gubrag. Para seniman yang berasal dari Cigudeg sadar bahwa jika mereka tidak bersatu maka akan menimbulkan berbagai kendala dalam menyelesaikan masalah yang datang. Pada tahun 1983 dari Abah Sadikin menyampaikan gagasan untuk membentuk sebuah kelompok yang akan mengatur dan mengurus kesenian Angklung Gubrag. Gagasan ini disambut baik oleh seniman Angklung Gubrag lainnya, sehingga pada tahun yang sama didirikan sebuah kelompok kesenian yang diberi nama Padepokan Seni Angklung Gubrag Cipining. Padepokaninimerupakan sebuah upaya untuk menampung aspirasi seniman atau pemain Angklung Gubrag yang berada diCigudeg. Melaluipadepokan, para seniman bisa bertukar pikiran untuk memajukan kesenian Angklung Gubrag.

Kedua, mengubah bentuk pertunjukan kesenian angklung gubrag. Untuk mempertahankan keberadaan Angklung
Gubrag, seniman melakukan mulai merubah bentuk pertunjukan Angklung Gubrag, supaya tidak hanya digunakan sebagai media ritual namun juga sebagai sarana hiburan. Perubahan ini bertujuan agar seni pertunjukan Angklung Gubrag tidak hanya dapat dinikmati oleh sebagian masyarakat, namun dapat diterima pula oleh masyarakat secara keseluruhan. Selain itu, agar cakupan pengenalan kesenian ini semakin luas.

Selain melakukan upaya pelestarian dalam padepokan, para seniman dari Cigudeg juga menjalin kerjasama dengan kelompok seni lainnya. Mereka berusaha menyebarkan kesenian Angklung Gubrag ini dengan cara mengajarkannya kepada orang-orang yang tertarik dengan kesenian dari para leluhur mereka. Padepokan Seni Angklung Gubrag bekerjasama dengan Kampung Budaya Sindangbarang dan Padepokan Pusaka Karuhun. Kampung Budaya Sindangbarang terletak di Desa Sindangbarang, Bogor. Kampung Budaya inimerupakantempatpemeliharaanbudaya Sunda khususnya kesenian yang berasal dari Bogor dan sudah berstatus sebagai tempat wisata. Sedangkan Pusaka Karuhun merupakan padepokan yang terletak di Kecamatan Jasinga, Kabupaten Bogor. Padepokan ini merupakan tempat yang melestarikan kesenian Angklung Gubrag dan Pencak Silat Cimande. Hal tersebut memperlihatkan bahwa Padepokan Seni Angklung Gubrag tidak pilih-pilih dalam mengajak kerjasama. Kerjasama yang dilakukan yakni mengajarkan cara bermain Angklung Gubrag kepada seniman yang berasal dari Sindangbarang maupun Pusaka Karuhun. Selain itu, ketiga tempat pelestarian budaya ini sering melakukan acara-acara kesenian bersama seperti 
upacara Seren Taun.

Upaya pelestarian selanjutnya yang dilakukan oleh Padepokan Seni Angklung Gubrag yakni berusaha untuk meregenerasi para pemain Angklung Gubrag. Proses pelestarian Angklung Gubrag tidak akan ada artinya apabila hanya pemain tua atau senior yang bisa memainkan dan paham mengenai kesenian tersebut. Sehingga para seniman juga memberikan pengajaran kepada generasi muda. Pewarisan budaya ini dapat dilakukan dengan cara melibatkan para generasi muda dalam latihan-latihan sehari-hari dan mengajak mereka menjadi bagian dari pertunjukan sejak kecil. Hal ini diharapkan dapatmenumbuhkankepedulian mereka terhadap seni Angklung Gubrag.

Selain kepada para pemuda, kesenian ini juga diajarkan kepada anak-anak pada usia Sekolah Dasar. Hal ini bertujuan agar minat masyarakat terhadap kesenian tradisional daerahnya tidak hanya tumbuh pada kalangan masyarakat dewasa tetapi juga mencapai masyarakat usia anakanak dan remaja. Pelestarian kesenian tradisional tidak bisa dipisahkan dari minat masyarakat pendukungnya. Untuk menumbuhkan minat para pemain muda untuk belajar dan berlatih Angklung Gubrag, pengurus dan pelatih padepokan seringkali memberikan reward atau hadiah. Selain itu upaya lain adalah dengan sering menampilkan pertunjukan yang dimainkan oleh anak-anak, sehingga semangat anakanak akan semakin terpacu dan orang tua pun diharapkan mendukung kegiatan yang dilakukan oleh putranya.

Terakhir, upaya yang dilakukan oleh seniman adalah mengadakan kerjasama dengan pemerintah. Dengan bekerjasama dengan pemerintah diharapkan dapat membantu perkembangan padepokan dalam mengembangkan seni Angklung Gubrag, baik bantuan secara materiil maupun non materiil. Kerjasama ini tidak terlepas dari tugas dan kewajiban pemerintah dalam pelestarian kesenian daerahnya. Dalam menjalankan tugasnya untuk melestarikan dan memperkenalkan kesenian daerahnya, Dinas Pariwisata dan Kebudayaan Daerah Kabupaten Bogor mengacu pada Peraturan Menteri Pendidikan Dan Kebudayaan Republik Indonesia Nomor 85 Tahun 2013 Tentang Standar Pelayanan Minimal Bidang Kesenian.

Undang-undang tersebut menjelaskan bahwa pemerintah daerah wajib memperkenalkan dan menampilkan kesenian daerahnya. Berdasarkan data yang didapatkan dari pihak Dinas Kebudayaan dan Pariwisata Kabupaten Bogor, pemerintah telah berusaha memberikan kesempatan bagi seniman daerah Bogor untuk tampil dan memperkenalkan keseniannya. Dukungan yang diberikan pemerintah diantaranya dengan mengadakan pagelaran seni dimana setiap kesenian akan ditampilkan. Biasanya ditampilkan pada acara-acara besar, seperti pada acara ulang tahun Kabupaten Bogor.

Kemudian pemerintah daerah juga harus mempunyai tempat atau gedung untuk menampung penampilan dan aspirasi dari setiap kesenian yang ada di wilayahnya. Kabupaten Bogor sendiri sudah mempunyai gedung yang digunakan untuk penampilan acara-acara kesenian yakni Gedung Kesenian yang bertempat di wilayah Cibinong yang merupakan Ibukota Kabupaten Bogor. Di tempat inilah setiap tahunnya sering ditampilkan kesenian yang berasal dari wilayah Bogor, salah satunya yakni kesenian Angklung Gubrag yang berasal dari Kecamatan Cigudeg. Selain itu, pemerintah Kabupaten Bogor juga pernah 
memberikan bantuan kepada seniman Angklung Gubrag melalui ketuanya untuk membangun padepokan yang akan berguna bagi mereka untuk tempat berlatih. Pemerintah juga berupaya untuk melakukan pendokumentasian kesenian Angklung Gubrag. Hal ini dilakukan agar kesenian Angklung Gubrag dapat terjaga dengan baik. Tidak hanya dilestarikan dengan cara lisan dan perbuatan tapi juga dilengkapi dengan catatan dan dokumen lengkap mengenai sejarah muncul dan perkembangan Angklung Gubrag.

\section{SIMPULAN}

Alat musik Angklung Gubrag sudah digunakan sejak lama oleh masyarakat Cigudeg sebagai media ritual dalam upacara Seren Taun yang bertujuan untuk memuja Nyi Pohaci. Penggunaannya dalam upacara ritual dipengaruhi oleh pola pikir dan keyakinan masyarakat yang masih sederhana yakni hubungan antara manusia dengan alam. Peran manusia dalam menjaga keseimbangan hubungan tersebutadalah dengan menyenangkan hati Sang Pencipta Alam. Dalam kepercayaan masyarakat Cigudeg, Pencipta Alam dikenal dengan Nyi Pohaci yang dikenal sebagai Dewi Kesuburan. Masyarakat Cigudeg selalu mengadakan upacara ritual setiap habis masa panen, sebagai satu cara untuk menolak bala (pencegah kesialan dan kegagalan panen). Pada perkembangannya, Angklung Gubrag dianggap sebagai bagian dari kebudayaan yang menjadi identitas masyarakat pendukungnya, khususnya masyarakat Cigudeg.

Kesenian Angklung Gubrag mengalami perkembangan bentuk pertunjukan antara tahun 1983-2013. Hal ini disebabkan oleh perubahan yang terjadi pada masyarakat seperti kepercayaan terhadap hal-hal magis semakin ditinggalkan dan juga kurangnya minat terhadap kesenian tradisional Angklung Gubrag. Faktor tersebut mendorong seniman untuk mengubah bentuk pertunjukan Angklung Gubrag menjadi kesenian yang bersifat hiburan. Sejak tahun 1990-an, Angklung Gubrag mempunyai fungsi ganda yakni sebagai media ritual dalam upacara Seren Taun dan juga pertunjukan hiburan. Perkembangan bentuk pertunjukan seni Angklung Gubrag menyebabkan beberapa perubahan dalam pertunjukan Angklung Gubrag diantaranya terjadi penambahan peralatan dalam pertunjukan, penambahan lagu, serta penambahan gerakan yang bertujuan agar menambah nilai estetika pada kesenian Angklung Gubrag.

Dalam upaya pelestarian kesenian AngklungGubrag,senimantelahmelakukan beberapa upaya untuk melestarikan kesenian tersebut, diantaranya yakni mengubah bentuk pertunjukan Angklung Gubrag menjadi pertunjukan yang bersifat modern, mendirikan Padepokan Seni Angklung Gubrag, bekerjasama dengan kelompok kesenian lain seperti Kampung Budaya Sindangbarang dan Pusaka Karuhun (Jasinga), mengadakan pewarisan kesenian angklung Gubrag pada generasi muda, dan mengupayakan adanya kerjasama dengan pemerintah. Upaya yang dilakukan oleh seniman tidak terlepas dari keinginanmerekauntukdapatmelestarikan dan memperkenalkan Angklung Gubrag kepada masyarakat, terutama di tengah masyarakat asalnya. Melalui pelestarian ini masyarakat terutama generasi muda tahu dan paham mengenai kesenian yang sudah diturunkan oleh leluhur sejak lama, terutama nilai-nilai kegunaan Angklung Gubrag yang dapat menjadi pelajaran bagi 
masyarakat masa kini.

Selain pihak seniman, pemerintah Kabupaten Bogor telah melakukan upaya untuk melakukan pelestarian Angklung Gubrag baik secara moril maupun materil. Secara moril, pemerintah Kabupaten Bogor telah memberikan kesempatan seni Angklung Gubrag untuk tampil dalam berbagai acara kesenian, di antaranya acara rutin yang menjadi program tahunan pemerintah yakni pada ulang tahun Kabupaten Bogor, acara gelar pameran dan pertunjukan kesenian, serta acara perkenalan seni budaya baik yang dilaksanakan di daerah Kabupaten Bogor maupun luar daerah. Secara materil, pemerintah telah memberikan bantuan dana untuk membangun padepokan

\section{DAFTAR PUSTAKA}

Gottschalk, L. (2008). Mengerti sejarah. Jakarta: Universitas Indonesia Press

Kurnia, G. dkk. (2003). Deskripsi kesenian Jawa Barat. Bandung : Dinas Kebudayaan dan Pariwisata Jawa Barat dan Pusat Dinamika Pembangunan UNPAD.

Masunah, J. dkk. (2003). Angklung di Jawa Barat : sebuah perbandingan.
Bandung: Pusat Penelitian dan Pengembangan Pendidikan Seni Tradisional Universitas Pendidikan Indonesia (P4ST UPI).

Peraturan Menteri Pendidikan Dan Kebudayaan Republik Indonesia Nomor 85 Tahun 2013 Tentang Standar Pelayanan Minimal Bidang Kesenian.

Sjamsuddin, H. (2007). Metodologi sejarah. Yogyakarta: Ombak

Soekanto, S. (2007). Sosiologi suatu pengantar. Jakarta: Raja Grafindo Persada.

Soepandi, A. (1974). Khasanah kesenian daerah Jawa Barat. Bandung:Pelita Masa.

Sumardjo, J. (2011). Sunda : pola rasionalitas budaya. Bandung : Kelir

Yoeti,O.A.(1985).Melestarikan senibudaya tradisional yang nyaris punah. Jakarta: Proyek Penulisan dan Penerbitan Buku/Majalah Pengetahuan Umum dan Profesi Departemen Pendidikan dan Kebudayaan. 